\title{
Recovering the habitat concept within urban morphology
}

Teresa Marat-Mendes, Maria Amélia Cabrita

Instituto Universitário de Lisboa ISCTE-IUL, Lisboa, Portugal

E-mail: teresa.marat-mendes@iscte.pt,mamelia@gmail.com

\begin{abstract}
The purpose of this paper is to provide an opportunity to explore the Habitat debate within ISUF. We quest that within this concept, as placed by Anne Vernez Moudon in her inaugural paper to Urban Morphology, there is an intrinsic call towards a needed equilibrium between the various dimensions of urban form and a trans-disciplinary approach to the study of urban form, which deserves further investigation. This paper presents the first results of an on-going investigation, which seeks to recuperate the concept of Habitat within urban morphology, while identifying how the concept of Habitat was first explored in a number of international organizations, mostly by the geography and architecture fields, and how did it evolved over time. The early results of this investigation expose the impacts of such evolution on the various problematic and scales of approach of the urban environment, through various historically, disciplinary and geographical contexts. Finally it is believed that the promotion of the study of Habitat today, throughout the integration of typo-morphology, as a methodology, could reinforce the role of social sciences and of transdisciplinary practices within the study of urban form.
\end{abstract}

Keywords: Habitat, human dimension, interdisciplinary analysis, urban morphology, urban form

\section{Introduction}

The purpose of this paper is to provide an opportunity to explore the Habitat debate within ISUF. We quest that within this concept, as placed by Anne Vernez Moudon in her inaugural paper to Urban Morphology (Moudon, 1997), there is an intrinsic call towards an equilibrium between the various dimensions of urban form and a trans-disciplinary approach to the study of urban form, which deserves further investigation. However, as already recalled by Whitehand (2012) specific constrains seem to have inhibited the full concretization of such trans-disciplinary efforts over time, namely the further specialization of the disciplinary areas. Consequently, as argued by MaratMendes (2016), the contributions of the different scientific areas to the development of the study of urban form has been not uniform, whereas those whose focus is mostly placed on the physical dimensions of urban form have gained greater attention and enactment when compared to those that focus on the social dimensions of urban form, thus affecting in turn the above-needed equilibrium above identified by Moudon $(1997,1987)$ and Whitehand (2012).

Furthermore, supported on previous research which aimed to identify the foundations of urban morphology in Portugal conducted by Marat-Mendes and Cabrita (2015, 2016), and that has exposed the emergence of a typomorphological line of approach, followed by Portuguese geographers but also architects, that seem to have been influenced by a French school of thought, led by Albert Demangeon (Demangeon, 1926) contemporary to that of the German M. R. G. Conzen (1960), this paper exposes the results of an on-going investigation, which seeks to recuperate the concept of Habitat within urban morphology, to promote a more trans disciplinary and well balanced use of the various dimensions 
that concur to the study of urban form. Complementary, supported on information that confirms the close articulation between the thematic issues considered by architects either in Portugal or internationally, such as the Habitat issue, with the main programmatic and thematic goals under considerations by institutions such as the United Nations (Deyong, 2011; Marat-Mendes and Cabrita, 2015), this investigation aims to contribute to clarify the potential role that the Habitat issue had on enhancing the trans-disciplinary efforts among different organizations and disciplinary backgrounds, including political agendas, in regard to the study of the rural but also urban environment while engaging also with the social domains, and therefore its pertinence for current research. Bringing back the discussion of the Habitat concept within urban morphology today reveals however an opportunity to rethink the foundations of urban morphology itself.

To do that, this paper will first identify how the concept of Habitat was initially defined and explored by a number of seminal works, which the authors of this paper have identified as seminal to the study of urban form in Portugal, but that has revealed also an important international perspective. Secondly, it exposes how such concept evolved throughout specific historical, disciplinary and methodological contexts. And thirdly, it reveals the impact of such evolution on the various problematic and scales of approach by those to which the Habitat issue was central for the study of urban from, including some contemporary contributions from various interdisciplinary areas, which seem to be recuperating that concept, although not explicitly. Thus a draft of the mapping of the evolution of the concept of Habitat is here provided, while revealing the levels of attention, which were being gained at different scientific areas, mostly geography and architecture.

Following this introduction, this paper provides a brief summary of the concept of the habitat, as proposed by well recognized international organizations and therefore it is organized in three parts. The first part exposes the methodology that was followed by the present investigation. The second parts attempts to define the Habitat concept, while the third parte identifies how did the habitat was explored within Geography a Architecture, respectively. Finally, some brief conclusions portrait the main initial lines of thought that have been identified by the present research.

Methodology

The methodology followed by this investigation was twofold. First, it involved a survey of the main sources, which have informed this investigation in terms of the discussion of the 'Habitat', as an intrinsic issue within the study of urban form. This survey was conducted throughout sources both from the geography and architecture domains, which have been identified in previous work conducted by Marat-Mendes and Cabrita (2015, 2016).

These sources were retrieved from two wellknown international organizations, because in a specific time of history they dedicated special attention to the Habitat issue, wherein proposing specific commissions to work on such issue. Respectively, the: i) International Geographical Union (IGU) which is an international, non-governmental, professional organization devoted to the development of the discipline of Geography, found in 1922 and that is still active nowadays, and the ii) Congrès Internationaux D'architecture Moderne (CIAM), or International Congresses of Modern Architecture, which is an organization that was founded in 1928 and dismantled in1959, and that was devoted to the spreading of the modern principles in all the main domains of architecture, such as landscape, urbanism, and many other areas.

The identified commissions were the 'Commission of the Habitat Rural' promoted by the IGU, and the 'Comission sur la definition de l'Habitat' and the 'Commision sur la grille de l'Habitat', thee last two promoted by the CIAM for the preparation of the ninth congress of this organization, named as 'Charte du habitat'.

Secondly, this research involved an analysis of the evolution of the concept of 'Habitat' in both identified organizations, but also in a number of other researchers conducted about the thematic under consideration. The goal was to retrieve how has such concept developed 
over time, and how the main interests and problematic under consideration by both geographers and architects, interested into the study of the Habitat seem to have advanced over time.

Thus a mapping of the evolution of the Habitat concept appears important to be clarified, wherein confronted to specific disciplinary, historical and methodological contexts under analysis by the present investigation.

\section{The Habitat}

The definition of Habitat is not straightforward, neither unanimous. At present the Oxford Dictionary defines it as the "natural home or environment of an animal, plant, or other organism'. However, the well-recognized international organization United Nations agency for Human Settlements and Sustainable Urban Development (UN-Habitat) places the debate of the Habitat within the urban dimension. It is precisely on the Report of the Habitat III, where a reflection about the twenty years of urban development analysed by the United Nations is promoted, since Habitat II, and where Habitat is then identified as a durable urban development for living, which should not have a precarious character. A clear message for the need to combat poverty but also precarious housing is therefore underlined, together with the need to identify and implement planning mechanisms which go in line with the goals of the UN-Habitat III report, but also add continuity to those established at the previous conference of UN-Habitat in 2014. The main goal of the UN-Habitat is therefore to improve the living conditions of housing and human settlements, while focusing on the most deprived areas of the world.

From the above it is clear that the contemporary problems which affect humanity, such as the rapid urban development of the world, wherein more that $50 \%$ of the population leaves already in cities has obliged organizations such as UN-Habitat to place their focus on the urban dimension of the humanity problems, and in particular on housing. The same occurred 72 years ago, at the first conference promoted by the United
Nations, nevertheless the world was not yet so urbanized as today. Durability of shelter and good conditions appears to be the main flags of present urban Agendas of this institution, in a way to promote a Sustainable Development.

On the other hand, if one identifies the concept of Habitat within the 'Dictionaire de l'urbanisme et de l'amanagement' (Merlin and Choay 1988) will find that its meaning is concentrated on the concept of housing, although it starts by identifying the wide spectrum of the concept. The need for housing development in the second half of the twentieth century, immediately after the second world war, seems to have been determinant for modern movement postulate the need of improving the general living conditions of housing and urbanism, while confronting it to the primitive and degraded current housing conditions (Merlin and Choay, 1998: p.323330).

Fijalkow and Lévy (2008) on their analysis about the evolution of the study of the urban habitat in France between 1900 and 2000, from the urban geography point of view, indicate three distinct directions within the first half of twentieth century. One, which was more rural and regionalist, as a consequence of the rural habitat, and two others which have followed inspiration in Le Play and the hygienist ideas, respectively. Furthermore, these authors claim that with the advent of the World War II the focus of the Geography did radically changed, alongside with the emergence of the massive urbanization issues as the new thematic issue contributed to the disappearing of the geography of the Habitat, but also of housing, an issue which was intrinsic articulated with habitat by the geographers.

It is precisely aware of the volatility that the concept of Habitat assisted throughout time, that this present investigation sought important to delineate the evolution of the various ideas associated to the concept of Habitat, expressed both in geography but also in architecture. The period of time under analysis runs from the end of nineteenth century, through a period of time which is considered by the authors of this paper as the golden period of research on the Rural Habitat, which took place between the two World Wars, until the almost disappearing 
of the issue of the Habitat within the urban question as recalled by Fijalkow (2008) in 1960's. This is done while considering the needs of the present context, which is favourable for an interdisciplinary reflection about the values that a thematic historiography can contribute, including to urban morphology. Furthermore, it is hoped that the preliminary results extracted by this research can contribute to the reading of transitions processes and interests to which society has faced in terms of the thematic issues, methodologies and contexts that have informed those that studied the human environment, including the landscape, settlements, cities but also housing, independently of being rural or urban, but also ways of life.

The lessons that we which to retrieve, although modest, if considering the amount of work that is still to be done on this issue, hopes to stimulate further understandings and investigations about the opportunity of reconsidering the habitat issue as an opportunity to join issues which have been segregated, because of specialization of disciplinary areas, but which should be better articulated if a better living environment is really ambition by urban morphologists in order to respond also the needs of contemporary society, as urged by the Sustainable Development Agenda (UNHabitat).

Our own definition of Habitat is that it is the overall phenomena that are associated to the human occupation of the territory, including its economic, social, cultural and historical dynamics and that is interrelated with the conformation of its physical and material evolution, at all its different scales of occupation, from the elementary construction to the more complex aggregation, as the city or the metropolis. As indicated by Moudon (1989) Human Habitat is the core and the heart of the urbanization process. It physically expresses the result of different economic and building activities, but also of design options.

It was mainly during the $40 \mathrm{~s}$ and $50 \mathrm{~s}$ of the twentieth century that we have identified a widespread interest into the study of the Habitat in the most important architectural and geographical international organisations, including the Congrès Internationaux dArchitecture Moderne (CIAM), the Union
Géographique Internationale (IGU), as well as in the main agendas of international organizations focused on the human development, such as the above identified United Nations (UN, 1950). Furthermore, the focus on such Habitat Agenda was places on a rural dimension, which contributed to designate it as the Rural Habitat. However, despite the geographers were successful on defining such concept, the architects in turn, as argued by Mumford (2000, p. 268) have never defined the concept of Habitat with the same accuracy as they defined the four functions expressed in 'Athens Charter'.

\section{The Habitat within Geography and Architecture}

The Geography of Settlements is commonly regarded as seminal to the foundation of the Urban Morphology (Gauthiez, 2004 and Heinberg, 2007), Human Geography (stone, 1965) but also Urban Geography (Fialkow, 2008). Introduced as an object of study within geography, the human habit, has allowed an interdisciplinary vision about the relationships between the natural and the physical environment but also the forms of human occupation of the territory (landscape), associated to the ways of life and economic resources.

The Geography of Settlements represents the search for those forms, while focusing on the human settlements, buildings and complementary structures, wherein searching for the patterns of agglomeration of such constructions, and trying to ordinate and classify them by types, including houses or settlements, according to the level of proximity among those constructions, whereas their relative positions within a specific geographical area.

It was precisely under this context that the investigation of the Rural Habitat was incentivized by Albert Demangeon (18721940), whom would integrate such topic in 1925 within the International Congresses of the Union Geographique Internationale, and promote the 'Comission de l'Habitat Rural', which was translated to English as the 
'Commission on Types of Rural Settlement' in order to study the problem of the rural habitat. According to Heineberg (2007:p.5) 'German urban morphology has a long history. It was a progenitor of the Conzenian tradition in Britain'. The development of urban morphology owes largely to the German contributions during the first three decades of twentieth century, but also the contribution of M. R.G. Conzen (19072000) whom was decisive on the foundation of a School of thought in England, 'essentially German' (Heineberg, 2007: p.6). In particular, the location and the layout of towns were developed under such scope, guided mostly by the work of Geographers such as Otto Schluter (1872-1959) and Friedrich Ratzel (18441904), but also other German contributions, whom have allowed to develop the concept of cultural landscape, urban landscape, as a basis for setting this early view of townscapes within a longer-term, on a cross-disciplinary perspectives. Oliveira (2016) and Oliveira and Monteiro (2014) have identified from previous Jeremy Whitehand's publications references a number of influential antecedents for the work and ideas of M. R. G. Conzen, mostly German. Additionally, Whitehand (2001) confirms that it was precisely the German experience, more than his pre-war years in British Town planning and subsequent work in Geography under H. J. Fleure direction at the Manchester University that influenced M. R. G. Coznen's work on the study of Alnwick.

Stone (1965) considers that both German and French geographers of the 19th century were influential on the development of the Geography of Settlements. Furthermore he identifies Ratzel's anthropogeography close to the French human geography developed in later ninetieth century in France, whereas this later influenced by Vildal de la Blanche regional approach.

It would be precisely Blanche's ideas and the work conducted by geographers whom have followed him that would contribute to separate the physical geography from the human geography in France. This was a very different situation from what happened in the United Kingdom as recalled by Larkham (1995).

It would be the human geography in France that would integrate the Habitat, mostly the
Rural Habitat, as one of its main object of study. Thus, until the middle of last century, the geography of the Habitat emerged as a sub-discipline within the general geography (Fidalkow and Lévy, 2008: p. 21).

Albert Demangeon (1893-1940) led for almost three decades the study of human geography, in France. In the various works published in the several Annales de Géographie, the principal subject was the dwelling, in terms of types and distribution (Demangeon, 1920) but also the description of the patterns of distribution of the rural houses and contiguous fields (from disperse through intercalary to agglomerated ones) (Demangeon, 1927). From all the work produced by Demangeon one should recall the investigation of the Rural Habitat, which has greatly influenced a numbers of disciples, such as M. A. Lefèvre in France and Belgium, but also the Portuguese geographer Orlando Ribeiro, for example. Furthermore, his exceptional contribution to the successive Commissions de L'Habitat Rural promoted by the IGU, are reported on the several Comptes Rendus of the International Congresses of Geography which took place between 1928 and 1949. It would be his questionnaire of regional geography published in 1909 and that would be later developed as the 'Un Questionnaire sur L'Habitat Rural'(Demangeon, 1926) that would influence worldwide a number of other studies about the rural habitat, including in Portugal, with important trans-disciplinary implications, for example between geography and architecture (Marat-Mendes and Cabrita, 2015).

It was precisely the study of the Habitat, as identified by Lefévre (1926) the most important field developed scientifically out from the human geography. Furthermore, the pertinence of the French geographers because although influenced by German studies (such as Ratzel), but also north American ones (the urban ecology from Chicago School), they have individualized themselves because traced a specific disciplinary field, while facing however the rapid changes from a dominant rural society to an urban society and an institutionalization of the territorial planning (Fidalkow and Lévy, 2008). Nevertheless, Stone (1965) claims that while withdrawal an eventual tendency to 
limit them to the dwelling characterization, the discussion of the concept of the rural habitat would contribute to join the French geographers between 1950's and 1960's from the definition attributed to the German geographers. Later, as recalled by Fijalkow and Lévy, 2008) the French urban geography would absorb the Rural Habitat and turn it to the sociology and the practice of planning, contributing on the late 1950 's to the 'geographical interest in rural settlement was being overshadowed by urban analysis and definitions went unpublished (Stone, 1965: p.354). Concluding, the results of the Geography of Settlements have been inadequate to the breadth of the sector. As a consequence, "a great variety of definitions and lack of agreement have led to confusions and lastly, the object of settlement geography is a disperse subject of specialized geography, leading to inadequate study of still existing rural settlements, as if to say, rural habitat" (Stone, 1965: p.355).

The integration of the study of the habitat as part of the human geography in France faced a great dispersion of meanings, by different authors, eventually contributing to the disappearance of the Habitat issue in the Human Geography field, between 1960 and 1970. This occurred precisely when human geography ambitioned to become an autonomous discipline and when Habitat was still the main object of study within the majority of the social sciences disciplines. It would be only in 2000 that geographers would give back attention to the Habitat (Fidalkow and Lévy, 2008).

When it comes to Architecture, it is possible to identify the issue of Habitat in the centre of the architect's debate, in the preparation of the ninth congress of CIAM, which would take place in Dubrovnik in 1956. The commission which was in charge to discuss the theme of CIAM 9, and that has meet at the Working Congress that took place in Sigtuna in 1952, has reported that it had decided not to define 'Habitat' as it would be a controversial task, because of the wide amplitude of available definitions, but instead to formulate an 'introduction to the theme of the ninth congress of CIAM, which was later accepted by most of CIAM members as the 'Charter de l'Habitat'. The work promoted by this commission was informed by a number of reports prepared by the different groups within the CIAM. The commission concludes that Habitat engages two specific dimensions, one that it is more concrete and another one that is more abstract. For the first one it includes everything that is more close to the materiality, and that results from the way that man organizes its constructions and artefacts within the habitat. For the second case, there is an idea of association that people do the habitat themselves.

The commission emphasizes the quality of the several reports which were prepared and subited by the different national CIAM groups for the 1952 meeting at Sigtuna, for the preparation of the CIAM 9 Congress. Moreover, it underlines that concrete problems were discussed within each group report, but that nevertheless it would be important for each group not loose the 'abstract' idea within the Habitat, that was not purely material one. An idea of complexity is underlined. Moreover, it is stressed that habitat is not the sum of several parts but instead an organized structure, that depends on everyone, and might change upon the pressure of individuals. A declaration of 'Habitat' was therefore endeavoured as 'Habitat n'est pas 'statique' mais en perpetuelle mobilité suivant la mobilité des hommes et de la societé. Son organisation est toujours renouvelée. Nous deéclarons qui'l n'est pas passif mais qu'il existe entre lui et les hommes un jeu perpétuel d'actions et de réactions, les hommes agisant sur cet Habitat en le pensant et en l'organisant, et cet Habitat réagissant sur les hommes en contribuant à les conditionner et, par conséquant, à les faire ce qu'ils sont" (in the Rapport of the Comission sur le Thème du CIAM, 1952).

Nevertheless, if one goes through the several national groups report, which have contributed to the discussion of the 'Charter de l'Habitat', will identify different topics of interest. From the single housing to the most complex urban structure, the discussion of the Habitat among the CIAM architects exposed a variety of interests, scales of approach and different levels of acceptance of trans-disciplinary perspectives. Additionally, it is also possible to identify distinct methodological approaches.

It was precisely this complex context that 
might have contributed to the separation of the Habitat issue within the work of two Commissions: 'Commission sur la définition de l'Habiat' and the 'Commission sur la grille de l'Habitat'. Whereas the first commission refused to define Habitat, but instead defined the thème of the Congress, the second commission became engaged in identifying the 'relationships' to be included on the Grille for the incorporation on the Charter (CIAM, 1952). The establishment of these commissions was approved at the $3 \mathrm{rd}$ meeting of the Congress of CIAM for the preparation of the CIAM 9, on the 28th June of 1952, in Sigtuna.

As it happened with the geographers it is possible to identify among the architects also dispersion on the understanding of the Habitat, despite the efforts of the CIAM organization in finding a general consensus.

Interestingly is the fact that also architects were getting interested on the Habitat issue, as geographers, but why this interest?; was it because of their close ties to the United Nations and the International Union of Architects as claimed by Deyong (2011); and what implications had this situation on the vanishing of the Habitat issue and the abandonment of the Charter de 1'Habitat when compared to the Charter of Athens?

A number of questions are provoked when one faces this architects involvement within the Habitat debated. However, when one looks in detail to some of the national groups work in particular, for example that of the Portuguese team that participated at the CIAM X in 1956, at Dubrovnik, will perceive that the Rural Habitat was an important issue. Furthermore, it is possible to identify common lines of interest to geographers whom were working the habitat issue at the time, well informed on Albert Demangeon's work and enquires on the Rural habitat (Marat-Mendes and Cabrita, 2015). Furthermore, the unpublished report of the Charter of Habitat, of Ciam 10, held in 1956 at Dubrovnik is structured in there parts, wherein it devotes its second part exclusively to the 'Charte de 1'Habitat', where it includes the Reports of the eight involved Commissions. The issues addressed by each commission were as follows. 1- Formulation of the Chart de l'Habitat; 2 - The present situation of the
Habitat; 3 - To select extracts from earlier work of CIAM with relevance to the Habitat; 4 - The problem of cluster; 5 - The problem of mobility; 6 - The problem of growth and change; 7 - Urbanization as part of the habitat; and 8 - Comission of Liason

As recalled by Stone (1965) the lack of a clear definition and the diffusion of ideas around the Habitat issue has contributed to its dissolution among geographers, when in presence of a stronger position as more concrete instruments and tools aloud for planning, including statistics and later on Geographical Information systems. But from the above, we might suppose that the same seems to have happened within architecture. If one recalls CIAM 8, in 1951, Habitat was then defined as the living conditions of the dwelling, at the individual dimensions, but with respect to collective life, implying the scale of living, the house and the city sector. The goal was to guarantee liberty, individuality and creativity conditions to promote diversity of typologies. At Sigtuna, in 1952, habitat was not more than l'Habitation, as expressed on the Report of Commission 4 for the discussion of the Charte de l'Habitat - "L'habitat (le logis, le bloc, l'unité, le secteur de ville etc...)" (CIAM, 1952). Whereas in CIAM 9, in 1956, the goals of the Habitat, were taken much closer to what Lefévre and the authors of this investigation have defined above.

\section{Conclusions}

The situation between the two world wars was substantially different from that after the Second World War in 1945, which contributed to development of a number of transitions and changes in all aspect of society, including ways of life and the definition of common goals. For example, the urban phenomenon will gain greater attention, even more than the need to reconstruct the cities or even the rural landscape.

While the development of geography as a scientific area emerges in the second half on nineteenth century, mostly cantered in Germany, with the proliferation of the most innovative ideas; in what regards to the Geography of 
Settlements or the Human Geography it would be in France that we will find, between the two world wars the continuity and the development of the geography discipline, however now focused on the study of the Rural Habitat, whereas trying to integrate with the same presupposes the urban habitat.

However, the complexity of the several realities in presence and other aspects of epistemological and methodological order will not support the persistence of the Habitat as an object of study, with the values and contents that the different approaches had added, mostly after 1945 when attentions were than turned into the cities, entities that would be continuously growth supported by capitalism.

From what was possible to conclude so far, is that from the scientifically point of view, Germany became ignored, contributing to the loss of an important line of thought, even until today, also due to linguistic and publicity motifs. In addition, the growing importance of urban geography and other disciplines, contributed to the emergence and the development of a practice of urbanism and urban and territorial planning, as we know today, to the disadvantage of the rural landscape, but also of other scientific areas of analytical character, including urban morphology, as geographical discipline. It would be in 1994, with the foundation of ISUF that a new multidisciplinary impulse was devoted to urban morphology and that would try to invite different visions, methods and linguistics backgrounds, a situation that the designation of the three schools of thought of ISUF would not be sufficient to portrait.

However, in what relates to the Habitat, as it is discussed in the investigation we purpose that it could integration throughout the typomorphological approach, wherein recuperating the concept of type within its various levels of analysis, from the housing opening to the territory, wherein suggesting at the same time its aperture to the social sciences and interdisciplinary practice.

\section{References}

CIAM (International Congress for Modern Architecture) (1952) Les Documents de
Sigtuna 1952, (CIAM: s.1.).

CIAM (1956) Report of CIAM 10 (CIAM, s.l).

CIAM (1951) Reports of commissions and meetings of the 8th CIAM Congres (CIAM, s.1.).

Conzen, M. R. G. (1960) Alnwick Northumberland: a study in town plan analysis (Institute of British Geographers, London).

Demangeon, A. (1920) ' $L$ 'habitation rural en France', Annales de Géographie, 29, 352375.

Demangeon, A. (1926) 'Un Questionnaire sur L'Habitat Rural', Annales de Géographie35 (196), 289-292.

Demangeon, A. (1927) 'Géographie de l'habitat rural', Annales de Géographie, 36, $1-23$ and $97-114$.

Deyong, S. (2011) 'Planetary habitat: the origins of a phantom movement', The Journal of Architecture 6 (2), 113-128.

Fijalkow, Y. and Lévy, J. P. (2008) 'Un siècle d'etude sur l'habitat français en géographie urbaine (1900-2000)'Annales de Géographie 4 (662), 21-41.

Gauthiez, B. (2004) 'The History of urban morphology', Urban Morphology 8 (2), 7189.

Heineberg, H. (2007) 'German geographical urban morphology in an international and interdisciplinary framework', Urban Morphology 11 (1), 5-24.

Larkham, P. J. (1995) Urban Morphology and Typology in the United Kingdom, in Petruccioli (ed) Typological Process and Design Theory (Seminar Proceedings, AKPIA, MIT, Cambridge) 159-177.

Moudon, A. V. (1994) 'Getting to know de building landscape: typomorphology', in Franck, K. A., Schneekloth, L. H. (eds.) Ordering space: types in architecture and design (Van Nostrand Reinhold, New York) 289-311.

Moudon, A. V. (1997) 'Urban Morphology as an emerging interdisciplinary field', Urban Morphology 13-10.

Moudon, A. V. (1989) 'The role of typomorphological studies in environmental design research' in EDRA Conference Proceedings 20: Changing Paradigms, 4148. 
Marat-Mendes, T. (2016) 'Physical, social and cultural dimensions of Urban Morphology: redressing the balance?' Urban Morphology 20 (2)167-168.

Marat-Mendes, T., Cabrita, M. A. (2016) ' $\mathrm{O}$ inquérito à Arquitectura Regional Portuguesa e a Antropologia: um caso de transversalidade metodológica', in Correia, J., Bandeira, M. (eds.) Os Espaços da Morfologia Urbana. Actas da $5^{\text {a }}$ Conferência Internacional da Rede Lusófona de Morfologia Urbana, PNUM 2016 (Universidade do Minho, Faculdade de Arquitetura, Guimarães) 667-678.

Marat-Mendes, T., Cabrita, M. A. (2015) 'A Morfologia Urbana na Arquitectura em Portugal. Notas sobre uma abordagem tipomorfológica', in Oliveira, V. O., MaratMendes, T., Pinho, P. (eds.) O estudo da forma urbana em Portugal (UPorto, Porto) 65-94.

Merlin, P., Choay, F. (1988) Dictionaire de l'urbanisme et de l'amanagement (Presses universitaires de France, Paris).

Mumford, E. (2000) The CIAM Discourse on Urbanism, 1928-1960 (MIT Press, Cambridge).

Oliveira, V. (2016) Urban Morphology: An Introduction to the Study of the Physical Form of Cities (The urban book series. Springer International Publishing, Switzerland).

Oliveira, V. Monteiro, C. (2014) 'As origens da morfologia urbana e a geografia alemã' Revista de Morfologia Urbana 2 (1), 37-46.

Stone, K. H. (1965) 'The Development of a Focus for the Geography of Settlement', Economic Geography, 41 (4), 346-355.

United Nations (1950) Yearbook of the United Nations 1948-49 (United Nations, New York).

Whitehand, J. W. R. (2012) 'Issues in Urban Morphology', Urban Morphology 16 (1), 55-65.

Whitehand, J.W.R. (2001) 'British Urban Morphology: the conzenian tradition', Urban Morphology 5(2), 103-109. 